\title{
John Edward Marr, Sc.D., F.R.S.
}

THE death of Professor Marr is a great loss to geological science. During the past generation he maintained the high reputation of the "Cambridge School" and was pre-eminent as a teacher. His former students are scattered all over the world, and many of them fill important posts in the teaching profession and on the staff of Geological Surveys. Born in I 857, he was a Lancashire man and most of his geological work was carried out in the Lake District. He was educated at Lancaster Grammar School and at St John's College, Cambridge, where he became a Scholar. He obtained a First Class in the Natural Science Tripos and was elected a Fellow of his College. Much of his training was obtained from Professor Bonney, who was his College Tutor. For some time he acted as a Lecturer in Geology under the University Extension Scheme, and for a period he acted as deputy for Professor A. H. Green at Leeds. In i 886 he was appointed University Lecturer in Geology at Cambridge, a post which he filled with such distinction that on the death of Professor Hughes in 1917 he was elected as successor to the Chair of Geology, which he held until 1930 when he retired on account of ill-health.

His special spheres of work were in physical and stratigraphical geology. He published numerous papers, the most important of which dealt with the older rocks of the Lake District and North-West Yorkshire. During his later years he devoted much attention to the Pleistocene and Recent Deposits of Cambridge and the adjoining areas.

Professor Marr was the recipient of many distinctions. He was elected a Fellow of the Royal Society of London in I89I, served on the Council for two years, and received a Royal Medal in I930. For a period he served as Secretary to the Geological Society of London, from which he received the Lyell Medal and the Wollaston Medal He was President of the Society in 1904-1906. In 1930 he was elected an Honorary Fellow of the Royal Society of Edinburgh.

He died at Cambridge on October 2, 1933, at the age of seventy-six.

Professor Marr will be greatly missed by a host of geologists to whom his teaching proved an inspiration.

T. J. J. 